\section{Salivary Contamination of Forage Selected by Esophageal Fistulated Steers Grazing Sandhill Grassland ${ }^{1}$}

\author{
JOE D. WALLACE 2 , D. N. HYDER, AND \\ G. M. VAN DYNE
}

Beef Cattle Extension Specialist, Department of Animal Science, Colorado State University; Range Scientist, Plant Science Research Division, Agricultural Research Service, U.S. Dept. of Agriculture; and Professor of

Biology, Natural Resource Ecology Laboratory, Colorado State University, Fort Collins, Colorado.

\section{Highlight}

The effect of saliva contamination on chemical composition of forage collected from esophageal fistulated steers grazing sandhill grassland was studied over four different seasons. Salivary contamination of grazed forage significantly increased the ash component but did not change other chemical constituents calculated on an organic matter basis. The increase in ash attributed to saliva varied with species of plants and season of grazing.

Placing esophageal fistulae in grazing animals advanced range and pasture nutrition research; forage samples collected from the esophagus are

\footnotetext{
${ }^{1}$ Scientific Series Paper No. 1656. Major support was provided by the Colorado Agricultural Experiment Station and W-94 regional project on Range Livestock Nutrition. The third author was supported primarily by National Science Foundation Grants GB-7824 and GB-13096. We thank K. L. Knox and A. H. Denham for their suggestions in this research and G. M. Ward, P. L. Sims and R. M. Hansen for their constructive reviews of the manuscript. Received May 31, 1971.

2 Presently Range Nutritionist, Dept. of Animal, Range, and Wildlife Sciences, New Mexico State University, Las Cruces.
}

more representative of forage consumed than are hand-collected samples (Van Dyne and Torell, 1964). However, forage samples obtained from an esophageal fistula are changed by saliva and mastication. The amount of change in chemical components of forage eaten and collected by esophageal fistulae remains somewhat controversial. Therefore, we evaluated the extent of salivary contamination in cattle-grazed forage collected at different seasons of the year.

\section{Consideration of the Problem}

Salivary contamination of esophageal-collected samples probably varies with the whole complex of factors influencing rate and composition of salivary flow. The rate of salivary flow varies with different types of feed (Bailey and Balch, 1961) and with level of food intake (Putnam et al., 1966). The $N$ (nitrogen) content of saliva varies among diets. In cattle (Bailey and Balch, 1961) and sheep (Lewis, 1957), urea $N$ levels in saliva varied with the level of ammonia produced by different diets. With low $\mathrm{N}$ intake, ruminants conserve $\mathrm{N}$ by reducing the excretion of urinary urea (Elliot et al., 1965), by recycling substantial amounts of urea $\mathrm{N}$ in saliva (Kay, 1966), and by direct infusion of urea from blood to the rumen (Houpt, 1959).

Minerals are the primary contaminant in fistula forage samples. Several workers have compared feeds of known composition with samples of the same feed collected from esophageal fistulae of cattle and sheep (Table 1). The ash content of forage eaten increased about 1 to $4 \%$. Ash contamination increased with an increase in dry matter or fiber content because dry and fibrous diets stimulated greater salivary flow (Kay, 1963). $\mathrm{N}$ and fiber percentages of forage generally were not changed by salivary contamination (Table 1).

Some of the controversy regarding salivary contamination arises from the calculation of constituent percentages on a dry matter as opposed to an organic matter basis. Since minerals are the main contaminant from saliva, percentage of organic constituents decrease with an increase in amount 
of contamination when expressed on a dry matter basis, but may remain unchanged when expressed on an organic matter basis. The errors in interpretation with the dry matter basis are illustrated below:

Dry matter basis Organic matter basis

Constituent

Clipped Esophageal Clipped Esophageal

Ash (\%)

8.0

Organic matter $(\%)$

92.0

8.9

Protein (\%)

4.22

Gross energy (kcal/g)

Fiber (\%)

42.6

5.7

\section{0}

89.0

100.0

100.0

8.4

9.7

9.4

4.05

4.59

4.55

41.4

46.3

46.5

$5.3 \quad 6.2$

6.0
Most of the differences which appear in the data expressed on a dry matter basis are non-existent, or of much less magnitude when expressed on an organic matter basis. This very critical point appears to have been overlooked by several workers; thus, it is difficult to conclude whether some differences reported (Table l) have any real meaning.

Relatively little is known concerning salivary secretion by ruminants at pasture. Salivary flow by grazing cattle has received virtually no attention. With sheep, Wilson (1963) found that salivary secretion varied with season on the same pasture. He estimated that daily flow rates could be as high as 30 liters on dry, mature forage. This estimate is two to five times greater than that presented by Kay (1963) for sheep fed hay and meal (6 to $16 \mathrm{l}$ /day). Salivary flow increases during eating (Bailey and Balch, 1961); thus, the longer time spent grazing as opposed to eating harvested food (Graham, 1965) probably explains the greater salivary flow in grazing sheep.

Increased saliva secretion by animals at pasture (as indicated by Wilson, 1963) coincides with water turnover com- parisons made with cattle (MacFarlane and Howard, 1966). The latter authors, using twin cattle with one member of each pair stall-fed and the other at pasture, found water turnover to be about three times greater in grazing cattle compared to those fed in stalls.

\section{Experimental Procedure}

The diets of cattle on eastern Colorado sandhill grassland were studied by collecting grazed forage from 8 esophageal fistulated steers during 5-day periods in June, July, September and December. Details regarding climate in the ared, the experimental pasture, forage collection procedure, and chemical and analytical methods were given by Wallace and Denham (1970).

To determine the extent of saliva contamination in grazed forage the chemical composition of esophageal samples was compared with that of hand-collected forage during each sampling period. Esophageal samples were collected from a steer grazing mixed grass at the end of lead rope for 30 minutes. The composition of the steer's diet was duplicated as closely as possible by hand. The stcer uscd in this manncr was extremely docile and grazed normally with the other steers.

Differences in chemical composition between paired samples collected in the above manner could be due to salivary contamination or imperfect duplication. To eliminate errors due to imperfect duplication of diet by clipping, unselected samples were collected by hand each period and divided into two parts. One part was soaked in fresh steer saliva for 1.5 hours and dried in a forced-air oven for comparison with the unsoaked part as suggested by Cook (1964). Prior to soaking in saliva, the sample was passed four times through a Wiley mill with the screen removed to approximate mastication.

Table 1. Observed changes in forage samples collected from esophageal fistulae when diets of known composition were fed.

\begin{tabular}{|c|c|c|c|c|c|c|c|}
\hline \multirow[b]{2}{*}{ Reference } & \multirow[b]{2}{*}{ Location } & \multirow[b]{2}{*}{ Diet } & \multirow{2}{*}{$\begin{array}{c}\text { Animal } \\
\text { class }\end{array}$} & \multirow{2}{*}{$\begin{array}{c}\text { Primary } \\
\text { contam- } \\
\text { inant }\end{array}$} & \multicolumn{2}{|c|}{$\begin{array}{l}\text { Other changes in } \\
\text { dietary sample }\end{array}$} & \multirow{2}{*}{$\begin{array}{c}\text { Basis on } \\
\text { com- } \\
\text { parison }^{2} \\
\end{array}$} \\
\hline & & & & & Increase & Decrease & \\
\hline Arnold et al. (1966) & Australia & Different fresh herbages & Sheep & Ash & None & None & OM \\
\hline Bath et al. (1956) & California & Chopped alfalfa & Sheep & Ash & None & None & $\mathrm{DM}$ \\
\hline Campbell et al. (1968) & Oklahoma & $\begin{array}{l}\text { Fresh Bermuda grass or } \\
\text { native pasture mix }\end{array}$ & Cattle & Ash & None & N, NFE, EE & $\mathrm{U}$ \\
\hline Cundy and Rice (1968) & Wyoming & $\begin{array}{l}\text { Alfalfa hay, haylage } \\
\text { and silage }\end{array}$ & Cattle & Ash & None & DM dig. & $\mathrm{DM}$ \\
\hline Hoehne et al. (1967) & Nebraska & $\begin{array}{l}\text { Prairie sandreed and } \\
\text { blue grama grasses }\end{array}$ & Cattle & Ash & $\mathrm{Cl}, \mathrm{P}$ & N, Ca, S. CHO & $\mathrm{U}$ \\
\hline Langlands (1966) & Australia & $\begin{array}{l}\text { Lucerne chaff and } \\
\text { fresh herbage }\end{array}$ & Sheep & Ash & $\mathrm{Na}, \mathrm{P}$ & $\mathrm{K}, \mathrm{OM}$ dig. & $\mathrm{OM}$ \\
\hline Lesperance et al. (1960) & Nevada & $\begin{array}{l}\text { Different alfalfa } \\
\text { and grass hays }\end{array}$ & Cattle & Ash & $\mathrm{CF}, \mathrm{P}$ & GE, NFE & U \\
\hline Lombard and Van Schalkwyk (1963) & S. Africa & $\begin{array}{l}\text { Different hays and } \\
\text { fresh herbages }\end{array}$ & Sheep & Ash & $\mathbf{P}$ & NFE & $\mathbf{U}$ \\
\hline McManus (1961) & Australia & Various roughages & Sheep & Ash & None & None & $\mathrm{OM}$ \\
\hline
\end{tabular}

${ }^{1} \mathrm{CF}=$ crude fiber, NFE $=$ nitrogen free extract, $\mathrm{EE}=$ ether extract, $\mathrm{DM}$ dig. $=$ dry matter digestibility (in vitro), $\mathrm{S}$. CHO = water-soluble carbohydrates, OM dig. = organic matter digestibility (in vitro), $\mathrm{GE}=$ gross energy.

${ }^{2} \mathrm{OM}=$ organic matter basis, $\mathbf{D M}=$ dry matter basis, $\mathbf{U}=$ unspecified. 
Table 2. Chemical composition of mixed grass forage collected by animal and by hand in different seasons.

\begin{tabular}{llllll}
\hline \multirow{2}{*}{$\begin{array}{c}\text { Component } \\
\text { and sample } \\
\text { collection }\end{array}$} & \multicolumn{5}{c}{ Season } \\
\cline { 3 - 5 } & June & July & Sept. & Dec. & Avg. \\
\hline $\begin{array}{l}\text { Crude protein (\%) } \\
\text { Animal }\end{array}$ & 13.7 & 7.6 & 5.8 & 4.1 & 7.8 \\
$\quad$ Hand & 13.3 & 7.5 & 6.9 & 4.2 & 7.7 \\
Acid-detergent fiber (\%) & & & & & \\
$\quad$ Animal & 46.6 & 47.2 & 52.8 & 57.1 & 50.9 \\
$\quad$ Hand & 45.9 & 49.0 & 51.5 & 56.9 & 50.8 \\
Lignin (\%) & & & & & \\
$\quad$ Animal & 4.9 & 5.1 & 8.5 & 9.2 & 6.9 \\
$\quad$ Hand & 5.1 & 7.2 & 7.5 & 8.9 & 7.2 \\
Ether extract (\%) & & & & & \\
$\quad$ Animal & 1.4 & 1.6 & 3.0 & 3.0 & 2.3 \\
$\quad$ Hand & 1.4 & 1.7 & 2.7 & 2.9 & 2.2 \\
Gross energy (kacl/g) & & & & & \\
$\quad$ Animal & 4.40 & 4.56 & 4.53 & 4.67 & 4.54 \\
$\quad$ Hand & 4.49 & 4.60 & 4.57 & 4.50 & 4.54 \\
Ash (\%) & & & & & \\
$\quad$ Animal & 8.0 & 7.5 & 9.5 & 10.4 & 8.8 \\
Hand & 7.1 & 6.4 & 7.5 & 8.6 & 7.4 \\
\hline
\end{tabular}

$\overline{{ }^{1} \text { All components except ash are given on an organic matter basis. }}$

\section{Results and Discussion}

Salivary contamination by steers grazing mixed grass increased the ash content of forage significantly $(\mathrm{P}<0.05)$ (Table 2). Furthermore, the amount of ash added by saliva increased with advancing plant maturity. Consequently, the concentrations of all other constituents were expressed on an organic matter basis. In this way, forage eaten by animals differed from forage collected by hand only in ash content.

In Table 3 comparisons in chemical composition were made between clipped herbage soaked in saliva and that left untreated. Differences in components other than ash were non-significant; and with ash the increases due to ensalivation followed trends similar to those shown in Table 2. The increase in ash content caused by saliva contamination was about $1 \%$ greater when the forage was eaten by animals (Table 2) than when clipped and soaked in saliva (Table 3 ).

Our results, like those of Wallace et al. (1972), indicate that the main discrepancy in chemical composition between actual diet samples and those simulated by careful hand-clipping may arise through salivary ash contamination and not through imperfect diet duplication.

Dry matter content of clipped herbage varied from $38 \%$ in June to $90 \%$ in December, and of esophageal forage samples from 22 and $24 \%$. Dry, mature forage had a greater absorbing capacity for saliva than less mature or green forage. Con-
Table 3. Chemical compotition of mixed grass herbage collected by hand and soaked in saliva in different seasons.

\begin{tabular}{llllll}
\hline \hline \multicolumn{1}{c}{$\begin{array}{c}\text { Componcnt } \\
\text { and sample } \\
\text { treatment }\end{array}$} & \multicolumn{5}{c}{ Season } \\
\cline { 2 - 4 } & June & July & Sept. & Dec. & Avg. \\
\hline Crude protein (\%) & & & & & \\
$\quad$ Soaked & 12.4 & 7.3 & 5.4 & 3.3 & 7.1 \\
$\quad$ Untreated & 12.1 & 7.9 & 5.4 & 3.4 & 7.2 \\
Acid-detergent fiber (\%) & & & & & \\
$\quad$ Soaked & 48.0 & 52.1 & 54.1 & 52.6 & 51.7 \\
$\quad$ Untreated & 49.2 & 52.0 & 53.8 & 53.2 & 52.0 \\
Lignin (\%) & & & & & \\
$\quad$ Soaked & 5.6 & 7.3 & 7.9 & 7.9 & 7.2 \\
$\quad$ Untreated & 5.8 & 6.7 & 8.2 & 8.6 & 7.4 \\
Ether extract (\%) & & & & & \\
$\quad$ Soaked & 1.8 & 1.7 & 2.1 & 3.2 & 2.2 \\
$\quad$ Untreated & 2.0 & 1.4 & 1.9 & 2.9 & 2.0 \\
Gross energy (kcal/g) & & & & & \\
$\quad$ Soaked & 4.64 & 4.53 & 4.60 & 4.51 & 4.57 \\
$\quad$ Untreated & 4.40 & 4.58 & 5.43 & 4.53 & 4.51 \\
Ash (\%) & & & & & \\
$\quad$ Soaked & 9.1 & 7.7 & 9.3 & 8.0 & 8.5 \\
$\quad$ Untreated & 9.1 & 7.6 & 8.2 & 6.8 & 7.9 \\
\hline
\end{tabular}

${ }^{1}$ All components except ash are given on an organic matter basis.

sequently, the ash contamination by saliva in grazed samples increased with advancing plant maturity (Tables 2 and 3). An increase in salivary flow with the consumption of drier forage (Wilson, 1963) was probably a contributing factor also.

In July, September, and December salivary contamination also was evaluated by grazing blue grama (Bouteloua gracilis). The amounts of ash contamination were consistently greater than when grazing the taller mixed grass. Increases in ash content of grazed forage over clipped samples were 1.6, 3.6 and $4.3 \%$ for July, September and December, respectively. The percentages of other chemical components, expressed on an organic matter basis, were unchanged by salivary contamination.

The large increases in ash content of blue grama forage collected from the esophageal fistulae during September and December are greater than expected by salivary contamination alone, and introduce an additional type of contamination resulting from grazing. The steers apparently consumed appreciable amounts of soil when grazing short, dry blue grama. Harris et al. (1967) also reported soil ingestion by cattle grazing short grass pastures.

The problem of correcting for ash contamination in grazed forage samples is not a simple one. The extent of such contamination appears to be related to maturity (or dry matter content) of herbage and to rate and composition of salivary flow. Reliable estimates of salivary flow and composition are difficult to ascertain (Kay, 1966). Thus, the 
logical approach in dealing with chemical data representing forage collected from esophageal fistulae is to express results on an organic matter basis.

\section{Summary}

Wc studied changes in chemical composition of cattle grazed forage brought about through exposure to saliva. As compared to hand clipped forage samples, those exposed to saliva contamination were significantly higher in ash content. The increase in ash attributed to saliva was greater with mature, dry forage than with green, succulent forage; and it was higher on blue grama grass than on taller mixed grass. Other chemical constituents, expressed on an organic matter basis, were not changed by ensalivation.

We demonstrated the need for reporting chemical composition data of grazed forage on an organic matter basis and reviewed factors affecting rate and composition of salivary flow in cattle and sheep.

\section{Literature Cited}

Arnold, G. W., J. Ball, W. R. McManus, and I. G. Bush. 1966. Studies on the diet of the grazing animal: I. Seasonal changes in the diet of sheep grazing on pastures of different availability and composition. Aust. J. Agr. Res. 17:543-556.

Bailey, C. B., and C. C. Balch. 1961. Saliva secretion and its relation to feeding cattle: 2 . The composition and rate of secretion of mixed saliva in the cow during rest. Brit. J. Nutr. 15:383-402.

Bath, D. L., W. C. Weir, and D. T. Torell. 1956. The use of esophageal fistula for the determination of consumption and digestibility of pasture forage by sheep. J. Anim. Sci. 15:1166-1171.

Campbell, C. M., K. S. Eng, A. B. Nelson, and L. S. Pope. 1968. Use of esophageal fistula in diet sampling with beef cattle. J. Anim. Sci. 27:231-233.

Cook, C. W. 1964. Symposium on nutrition of forages and pastures: Collecting forage samples representative of ingested material of grazing animals for nutritional studies. J. Anim. Sci. 23:265-270.

Cundy, D. R., And R. W. Rice. 1968. Salivary contamination by esophageal collection with steers. Western Sect. Amer. Soc. Anim. Sci., Proc. 19:19-54.

Elliot, R. C., W. D. C. Reed, S. H. W. Cmelik, and J. H. Topps. 1965. The effect of season and of supplementary feeding on the rumen contents of African cattle grazing subtropical herbage: I. Distribution of nitrogen and dry matter. J. Agr. Sci. 64:387-396.
Graham, N. McC. 1965. Some aspects of pasture evaluation, p. 231-242. In K. L. Blaxter (ed.) Energy metabolism. Academic Press Inc., New York and London.

Harris, L. E., V. R. Bohman, G. P. Lofgreen, C. J. Kercher, And R. J. Raleigh. 1967. Techniques for range livestock nutrition research. Utah Agr. Exp. Sta. Bull. 471. $86 \mathrm{p}$.

Hoemne, O. E., D. C. Clanton, and C. L. Streeter. 1967. Chemical changes in esophageal fistula samples caused by salivary contamination and sample preparation. J. Anim. Sci. 26:628-631.

Houpt, I. R. 1959. Utilization of blood urea in ruminants. Amer. J. Physiol. 197:115-120.

KAY, R. N. B. 1963. Physiology in the rumen. J. Dairy Res. 30:261-288.

KAY, R. N. B. 1966. The influence of saliva on digestion in ruminants. World Rev. Nutr. and Diet. 6:292-325.

LANGlands, J. P. 1966. Studies on the nutritive value of the diet selected by grazing sheep: I. Differences in composition between herbage consumed and material collected from oesophageal fistula. Anim. Prod. 8:253-259.

Lesperance, A. L., V. R. Bohman, and D. W. Marble. 1960. Development of techniques for evaluating grazed forage. J. Dairy Sci. 43:682-689.

LewIs, D. 1957. Blood-urea concentration in relation to protein utilization in the ruminant. J. Agr. Sci. 48: 438-446.

Lombard, P. E., And A. Van Schalkwyk. 1963. Changes in the composition of feedstuffs during sampling by means of an oesophageal fistula. S. Afr. J. Agr. Sci. 6:205-212.

MacFarlane, W. V., AND B. Howard. 1966. Water content and turnover of identical twin Bos indicus and Bos taurus in Kenya. J. Agr. Sci. 66:297-302.

McManus, W. R. 1961. Properties of roughage feedstuffs collected from esophageal fistulas. Aust. J. Exp. Agr. Anim. Husb. 1:159-163.

Putnam, P. A., R. Lemman, And R. E. Davis. 1966. Feed intake and salivary secretion by steers. J. Anim. Sci. 25: 817-820.

Van Dyne, G. M., and D. T. Torell. 1964. Development and use of the esophageal fistula: A review. J. Range Manage. 17:7-19.

Wallace, J. D., And A. H. Denham, 1970. Digestion of range forage by sheep collected by esophageal fistulated cattle. J. Anim. Sci. 30:605-608.

Wallace, J. D., J. C. Free, and A. H. Denham. 1972. Seasonal changes in herbage and cattle diets on sandhill grassland. J. Range Manage. 25:100-104.

Wilson, A. D. 1963. The effect of diet on the secretion of parotid saliva by sheep: III. Observations of the secretion by grazing sheep. Aust. J. Agr. Res. 14:808-814.

SRM Summer Meeting and

60th Anniversary Festivities, Great Basin Experimental Range

$$
\text { July 24-28, } 1972 \text { Ephraim, Utah }
$$

See April issue of Rangeman's News for complete details. 